\section{WHO looks for benefits from genetic engineering}

\author{
Peter Newmark reports on a recent \\ European meeting on the application of DNA
}

THE WORI.r) Health Organisation, in a symposium held last month at the Giovanni Lorenzini Foundation in Milan, showed its interest in the "scientific developments and practical applications" (the symposium subtitle) of genetic engincering. This is a sign of the times, for WHO's original concern was the danger of genetic engineering: the potential spread of disease carried by newly created microorganisms.

Four years on, the dangers seem less. Hazards are now spoken of as 'conjectural' not 'potential'. Offices and officers are not concerned with 'biohazards but with biosafety'. One must now accentuate the positive.

The negative began in 1974 shortly after new techniques opened the door to the experimental incorporation of foreign genes into those of bacteria (forming "recombinant DNA"). Cloning of the recombinant DNA by culturing the bacteria promiscd both academic and commercial rewards.

This was excellent news for those who wished to study the molecular structure, and ultimately function, of and including man. Better still for some was the possibility that bacteria into which had been incorporated the gene for, say insulin. would without hesitation decode the instructions and synthesise the hormone, at a commercial rate.

The darker side of such experiments, as envisaged in 1974, turned on the likely bacterial host for the foreign genes. It was the bacterium Escherichia escaped? the genes of higher organisms, up to

coli (E. coli), some strains of which (but not the laboratory kind) are pathogenic to man. Many strains of $E$. coli, can colonise the human gut. What if a laboratory $E$. coli, engineered to synthesise insulin, escaped, found its way into guts and there poured out insulin? Worse still, what if the gene that codes for the production of cholera toxin was incorporated in the E.coli that

Worried by these possibilities a group of scientists, including pioneers of the recombinant DNA techniques suggested a moratorium on experiments until precautions could be designed to match the supposed hazards. The moratorium triggered off an avalanche of meetings, concern, guidelines, rcgulations and bureaucracy.

It is hardly surprising that many of the speakers in Milan came to honour the pioneers but certainly not to praise them. Time and again regret was expressed that the moratorium had ever been called. Demands for a public recantation by the whole group were muted by the thought that ailing public confidence in scientists would hardly be resuscitated by the spectacle of erstwhile experts admitting that they had cried wolf.

Why have opinions changed so drastically in less than four years? The strongest view at the meeting was that the original worry came from a closeknit group of molecular biologists who had not taken enough trouble to consult experts in infectious diseases, medical microbiology and epidemiology. Furthermore evidence has been

Inside Fort Detrick, Maryland: built to the strictest safety standards

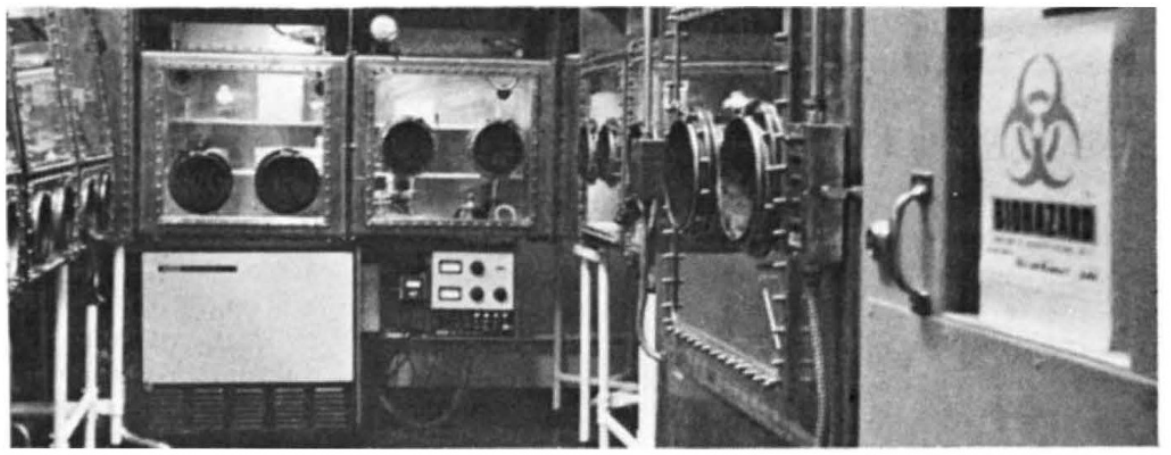

accumulated since 1974 to suggest that the laboratory strain of $E$. coli could not survive in the wild and that in any case the process of incorporating foreign into bacterial DNA is a naturally occurring one. The new evidence, however, does not seem substantial; those at Milan witnessed some unseemly clutching at straws.

Meanwhile regulations or guidelines have placed a variety of temporary harriers in the way of research. These have been met through both physical and biological containment. The former has involved building or equipping lahoratories to strict standards. The strictest of these have just been met for the first time in a laboratory,-- the Frederick Cancer Research Centre at Fort Detrick in Maryland. That will be followed, probably in six months time, by a high containment facility at the European Molecular Biology Laboratory in Heidelberg. Biological containment has been achieved by the "construction" of enfeebled vectors (the plasmids or phage that are used to carry the foreign DNA) or bacterial hosts. Most successful have been the American version of $E$. coli patriotically named $\chi 1776$ and the derivative of $\lambda$ phage optimistically named Charon. In Milan the question arose whether either were vigorous enough to be really satisfactory. Perhaps the British version devised in S. Brenner's laboratory in Cambridge and currently under test, will be better.

Another way to avoid the barriers surrounding the use of $E$. coli is to replace it by a host bacterium that is not pathogenic. Three different speakers in Milan described the development of Bacillus subtilis as an alternative host. Even if $E$. coli is as safe as some would claim, the availability of an alternative is going to be valuable since it is already clear that cloned genes may be expressed in one species but not in another.

Guidelines now exist in some form in every country which carries out recombinant DNA research. There are discrepancies between countries which sometimes cause professional jealousy. But J. Tooze, executive secretary of EMBO, suggested that harmonising guidelines internationally would be catastrophic, creating a stranglehold and preventing change.

The direction of change desired by all speakers in Milan was towards fewer restrictions. Already the French have achieved that. Their national regulations, adopted quietly three months 
ago, are an order of magnitude less restrictive than the National Institutes of Health $(\mathrm{NIH})$ regulations. Tooze hoped that Italy and Japan, still finalising their regulations, would follow France.

Several representatives of large industrial concerns were optimistic regarding the potential benefits of recombinant DNA technology to health and industry. The first benefit is likely to be improved bacterial strains, some providing increased yields of enzymes of industrial importance. Further ahead should lie the production of highly specific vaccines. For example, S. Falkow from Washing- ton University, Seattle, spoke of the potential as a cholera vaccine of a product of the cloned gene for the heat-labile $E$. coli enterotoxin.

The most tangible of the muchvaunted benefits of recombinant DNA, however, lies in the production of hormones. As far as can be judged the running in that race is being made by smaller industries spawned by the technology and with very close links to universities. In particular there is Genentech, a firm whose founders include $\mathrm{H}$. Boyer of the University of California, San Francisco. His university group has recently succeeded in chemically synthesising the gene for the hormone somatostatin incorporating it into a bacterial plasmid and then showing that when the plasmid entered host $E$. coli, the bacteria synthesised the hormone. The same techniques are now being applied to the production of insulin, a remarkable goal that is on target to being accomplished before the end of the year. Boyer estimates that the cost of insulin produced in that fashion should be no more than for that now purified commercially from slaughterhouse pancreatic tissue. Furthermore the insulin from Boyer's technique should be purer and could be of human origin and sequence.

\section{Friends of DNA fight back}

\section{David Dickson describes an unpublicised campaign by university} administrators to halt community participation in DNAlegislation

FOUR American universities have employed a Washington attorney as a professional lobbyist-although initially unregistered-in an attempt to prevent the passage of legislation allowing state or local participation in establishing regulations covering research using recombinant DNA techniques.

Already three of the four universities - Harvard, Stanford and Princetonface the possibility of state legislation covering such research; and Harvard has been made subject to local ordinances passed last year by Cambridge City Council.

At the fourth, Washington University in St Louis, little research involving recombinant DNA is being done, but an official said last week that they were concerned with the principle.

The issue of Federal preemptionFederal legislation that overrides state or local initiatives-lies at the heart of the current dispute. Public interest groups argue that local communities should be directly involved in drawing up regulations for research carried out in their midst, pointing to events at Cambridge to show how this can be done in what they claim to be a reasonable and moderate manner.

In contrast, many of the scientists argue the need for Federal preemption to provide uniform safety standards and prevent research workers moving to localities with less stringent regulations. Dr Philip Handler, president of the National Academy of Sciences told a Congressional Committee last week that the Federal preemption in the Bill now before the House of Representatives was "a particularly constructive feature".
Much of the opposition from the scientific community which led to last year's suspension of Congressional activity on DNA legislation was the result of a well-publicised campaign. At the same time, however, an unpublicised lobbying effort was conducted by university administrators concerned that DNA legislation could set a dangerous precedent for demands for community involvement in other areas of university activity.

Although the lobbying attempt has been done primarily through Harvard, more than 70 individuals at over 35 universities throughout the country have been involved through an informal network known as the 'Friends of DNA'. Only half of these are scientists; the rest are involved in university administration, in particular through offices of public affairs or similar liaison units.

The universities' concern at the implications of DNA legislation was first raised a year ago when Representative Paul G. Rogers, chairman of the Health and Environment Subcommittee of the House Committee on Interstate and Foreign Commerce, introduced an Administration-backed Bill which would have permitted state or local legislatures to impose conditions on DNA research more stringent than Federally-agreed guidelines determined by the National Institutes of Health.

Many scientists reacted strongly against this suggestion. On 26 April last year, a resolution signed by 13 members was passed by the National Academy of Sciences claiming that the proposed legislation would subject DNA research to "arbitrary regula- tions" at the local level which would "severely degrade" the capability of biomedical research.

Dr Harlyn Halvorson of Brandeis University, then president of the American Society for Microbiology, started a campaign among professional scientific societies through the InterSociety Council for Biology and Medicine whose objectives included "a single set of uniform national standards governing recombinant DNA activities". At the same time, the four private universities-Harvard, Stanford, Princeton and Washingtonagreed to contribute towards the expenses of a professional lobbyist, Ms Nan Nixon, who would argue for Federal-preemption in any DNA legislation.

She has conducted a vigorous lobbying campaign on the universities' behalf in collaboration with Mr Donald Moulton, until recently Harvard's assistant vice-president for Community Affairs, now working in commercial real estate and acting for Harvard as a consultant. (Although Ms Nixon has provided the Congress with details of her activities-as professional lobbyists are required to do-from the beginning of July 1977, she did not in fact register until February 28 this year, coincidentally handing in her registration two days before an article describing her activities as a registered lobbyist appeared in the Harvard Crimson.)

The scientific and university-based lobbyists soon met success. Mr Rogers and the Administration revised their Bill to state that the Secretary for Health, Education and Welfare could permit local, more stringent legislation only if it could be demonstrated that this was "necessary" (a word which has since taken on an important significance) to protect the health of people and the environment.

This was the form in which the Bill went before the House Commerce Committee, under the chairmanship of Representative Harley Staggers, last 